\title{
Cord blood resistin and adiponectin in term newborns of diabetic mothers
}

\author{
Maha H. Mohamed ${ }^{1}$, Ghada I. Gad ${ }^{1}$, Hala Y. Ibrahim², Mohamed S. El Shemi' ${ }^{1}$, Mohamed F. Moustafa ${ }^{1}$, \\ Shereen H. Atef ${ }^{3}$, Naglaa M. Ramadan², Shimaa M. El Saeid ${ }^{1}$
}

1Department of Paediatrics, Ain Shams Universit, Cairo, Egypt
2Department of Paediatrics, National Research Centre, Cairo, Egypt
${ }^{3}$ Department of Clinical Pathology, Ain Shams University, Cairo, Egypt

Submitted: 2 June 2009

Accepted: 1 July 2009

Arch Med Sci 2010; 6, 4: 558-566

DOI: 10.5114/aoms.2010.14468

Copyright $\odot 2010$ Termedia \& Banach

\section{Abstract}

Introduction: Adipose tissue can release hormones into the blood stream in response to specific extracellular stimuli or changes in metabolic status. Resistin, an adipose-secreted factor, is primarily involved in the modulation of insulin sensitivity and adipocyte differentiation. Adiponectin, an adipocyte-specific hormone with insulin sensitizing, anti-inflammatory and anti-atherogenic effects, is reduced in obesity and type II diabetes. The aim of the study was to assess the influence of maternal pre-existing diabetes on cord blood resistin and adiponectin at birth in relation to neonatal anthropometric parameters and cord blood insulin levels.

Material and methods: A total of 60 term newborns were prospectively enrolled and categorized into three groups: 20 were macrosomic infants of pre-gestational diabetic mothers (group I), 20 were non-macrosomic infants of pre-gestational diabetic mothers (group II) and 20 were healthy non-macrosomic infants born to non-diabetic mothers serving as controls (group III). Infants' anthropometric indices were recorded. Cord blood samples for glucose, insulin, resistin and adiponectin assay, together with maternal glycosylated haemoglobin were obtained.

Results: Serum insulin was increased while resistin and adiponectin were significantly decreased in infants of diabetic mothers (IDMs) compared to the control group. Serum glucose, insulin, resistin and adiponectin were comparable in group I and II. Cord serum resistin correlated positively with cord blood glucose in IDMs in both macrosomic and non-macrosomic groups. Cord serum insulin correlated positively with triceps skinfold thickness in all studied neonates. Cord serum resistin and adiponectin showed no correlation with neonatal anthropometric indices. Multiple regression analysis demonstrated that insulin, resistin and adiponectin together were highly correlated with birth weight, with adiponectin as the one responsible for this positive correlation.

Conclusions: Infants of diabetic mothers had elevated levels of cord serum insulin and suppressed levels of cord serum resistin and adiponectin, suggesting that the regulation of these metabolic pathways is probably operational before birth. Levels were comparable in both macrosomic and non-macrosomic neonates.

Key words: infants of diabetic mothers, resistin, adiponectin, macrosomic, insulin.

\section{Introduction}

Recent data have radically modified the concept of adipose tissue as one solely devoted to energy storage and release. Adipose tissue is also
Corresponding author:

Prof. Mostafa AL-Ahmady

Cairo, Egypt

E-mail:

osama000z@maktoob.com 
an important endocrine organ. It can release hormones into the blood stream in response to specific extracellular stimuli or changes in metabolic status [1]. These hormones are potentially involved in the regulation of energy homeostasis, adipose tissue development, and insulin sensitivity and may be the targets for nutrient interactions relevant to the likelihood of developing obesity with adverse effects on glucose and lipid metabolism [2].

Resistin, a recently cloned adipose-secreted factor, originally named by Steppan et al., for its resistance to insulin (resist + in[sulin]) [3], is primarily involved in the modulation of insulin sensitivity and adipocyte differentiation [4]. Resistin opposes the action of insulin in peripheral tissues and has a physiological function in the maintenance of blood glucose during fasting. It has been proposed to link obesity with diabetes [5]. Circulating resistin levels were higher in obese than lean individuals [6]. It has also been shown to inhibit adipogenesis in vitro [7]. Felipe et al. speculated that it may be a feedback regulator of adipogenesis and a signal to restrict adipose tissue formation [2].

Adiponectin is an adipose-specific plasma protein that improves insulin sensitivity and possesses antiinflammatory and anti-atherogenic properties [8]. Adiponectin is paradoxically reduced in obesity [9], despite being solely derived from adipose tissue in humans [10]. Both type 2 diabetes and relative insulin resistance in non-diabetic subjects are associated with decreased adiponectin concentrations [11].

Numerous studies have explored the role of adipocytokines in intrauterine growth [12]. However, at present, no information is available with respect to resistin and adiponectin in intrauterine growth and very little is known concerning the potential function of resistin and adiponectin in the paediatric population, especially in newborn infants.

In this study we hypothesized that, being closely related to insulin metabolism, serum resistin would increase and serum adiponectin would decrease in macrosomic infants of diabetic mothers and this might be correlated with anthropometric measures.

\section{Material and methods}

This prospective case control study was conducted on 60 neonates recruited from those delivered in the Obstetrics and Gynaecology Hospital and followed up in the Neonatal Intensive Care Unit, Ain Shams University Hospital, in the period from January 2007 to December 2007. The study was approved by the ethical committee of the Paediatric Department, Ain Shams University. Informed consent was obtained from mothers before recruitment.

These neonates were divided into the following groups. Group I included 20 full-term macrosomic (birth weight >4000 g) neonates to diabetic mothers. Group II included 20 full-term nonmacrosomic (birth weight: $2500-4000 \mathrm{~g}$ ) neonates to diabetic mothers. Infants were born to mothers with pre-gestational type I diabetes mellitus. Group III included 20 healthy full-term non-macrosomic (birth weight: 2500-4000 g) neonates of nondiabetic mothers, matched for age and sex, serving as controls. Neonates with preterm delivery, congenital or perinatal infection, congenital malformation, chromosomal abnormalities, infants whose mothers received corticosteroids or other hormonal therapy, infants with low Apgar scores, or with any evidence and/or history of metabolic disorders were not included in the study.

For all neonates complete medical and obstetric history was taken laying stress on duration of maternal diabetes, treatment, complications, control especially during late gestation, drugs or hormonal therapy, pre-pregnancy maternal weight, history of previous macrosomic neonates, stillbirth or abortion, perinatal history for premature rupture of membranes, mode of delivery, and Apgar score at $1 \mathrm{~min}$ and $5 \mathrm{~min}$. The gestational age of an infant was assessed by the mother's last menstrual period and/or early ultrasound dating, and cross-checked with the new Ballard score examination after birth [13].

Thorough clinical examination was performed and anthropometric measurements taken including: a) birth weight measured by a calibrated digital scale, b) supine crown-heel length, c) ponderal index, calculated as birth weight $(\mathrm{kg}) /$ length ${ }^{3}\left(\mathrm{~cm}^{3}\right)$, d) skinfold thickness measured with a skinfold caliper: 1) triceps skinfold thickness was measured halfway down the upper arm while the arm was lying in a relaxed position, 2 ) biceps skinfold thickness was measured by lifting a fold over the biceps in line with the anterior border of the acromial process and the antecubital fossa, 3) suprailiac skinfold thickness was measured by taking a fold just above the iliac crest along the anterior axillary line, 4) subscapular skinfold thickness was measured laterally just below the angle of the scapula.

Laboratory measurements were as follows:

- Maternal blood samples were collected at the time of delivery, put in EDTA tubes, centrifuged and the separated plasma stored at $-20^{\circ} \mathrm{C}$ for assessment of glycosylated haemoglobin $\left(\mathrm{HbA}_{1 \mathrm{c}}\right)$. $\mathrm{HbA}_{1 \mathrm{c}}$ was measured on a Beckman Synchron CX7 (Beckman Instruments, Galway, Ireland).

- Cord blood samples were withdrawn and divided into 2 parts: 1 part was withdrawn into plain tubes for glucose assay. The other part was withdrawn into plain tubes for clotting, centrifugation and serum separation then stored at $-70^{\circ} \mathrm{C}$ until used. 
- Random blood sugar was measured from the freshly separated serum using the glucose oxidase method [14].

- Serum insulin was measured by ELISA (Biosource INS-EASIA immunoassay kit) supplied by Euroupe S.A. (Rue de l'Industrie, 8-B-1400 Nivelles, Belgium). This assay employs the quantitative sandwich enzyme immunoassay technique. A monoclonal antibody specific for insulin (MAb1) is pre-coated onto a microplate. Calibrators and samples are pipetted into the wells and any insulin present is bound by the immobilized antibody. Another enzyme-linked monoclonal antibody directed against different epitopes of insulin (MAb2) was added to the wells. Following a wash to remove any unbound antibody-enzyme reagent, a substrate solution was added to the wells and colour developed in proportion to the amount of insulin bound in the initial step. The colour development was stopped and the intensity of the colour was measured.

- Serum resistin levels were detected by ELISA technique using the BioVendor Human Resistin immunoassay kit. It is a quantitative sandwich enzyme immunoassay technique in which goat polyclonal anti-human resistin antibody is precoated onto a microplate [3]. Calibrators and samples are incubated in the wells and any resistin present is bound by the immobilized antibody. A biotin labelled polyclonal anti-human resistin antibody was added to the wells. Following a wash to remove any unbound antibody-enzyme reagent, a substrate solution was added to the wells and yellow colour developed in proportion to the concentration of resistin. The colour development was stopped and the intensity of the colour was measured at $450 \mathrm{~nm}$.

- Serum adiponectin levels were detected by ELISA technique using the Biosource Human adiponectin
ELISA (Europe S.A. Rue de I'Industrie, 8-B-1400 Nivelles, Belgium). It is a quantitative direct enzyme immunoassay technique in which calibrators and samples are incubated with horseradish peroxidase labelled anti-adiponectin antibody coated onto a microplate [9]. After a thorough wash, the conjugate bound to adiponectin coated wells is allowed to react with hydrogen peroxide/TBM substrate solution. The reaction is stopped by addition of sulfuric acid solution and absorbance of the resulting yellow product is measured at $450 \mathrm{~nm}$.

\section{Statistical analysis}

Data were analysed using Statistical Package for the Social Sciences (SPSS) software computer program version 13. Quantitative data were described using mean \pm standard deviation; qualitative data were described in the form of numbers and percentages. Student's t-test of two independent samples was used to compare normally distributed quantitative variables while Mann-Whitney test was used for non- parametric data. $\chi^{2}$ test was used to compare qualitative variables. The correlation between continuous variables was analysed using Spearman correlation coefficient ( $r$ ). Multiple regression analysis was done with birth weight as the dependent variable, and insulin, resistin and adiponectin as the independent variables. The probability of error at or less than 0.05 was considered significant, at 0.01 and 0.001 highly significant.

\section{Results}

Demographic and laboratory characteristics of patient and control groups are listed in Tables I, II. Group I included 7 males and 13 females with mean birth weight $4.44 \pm 0.44 \mathrm{~kg}$, mean gestational age

Table I. Clinical and laboratory data of infants of diabetic mothers (group I and II) and control group

\begin{tabular}{|lcccc|}
\hline Data & $\begin{array}{c}\text { IDMs }(n=40) \\
\text { mean } \pm \text { SD }\end{array}$ & $\begin{array}{c}\text { Controls }(n=20) \\
\text { mean } \pm \text { SD }\end{array}$ & $t / Z$ & Value of $p$ \\
\hline Maternal age [years] & $30.30 \pm 3.62$ & $26.40 \pm 2.89$ & $t=4.192$ & 0.001 \\
\hline Maternal BMI [kg/m²] & $32.59 \pm 4.26$ & $28.86 \pm 3.39$ & $t=3.407$ & 0.001 \\
\hline Gestational age [weeks] & $37.48 \pm 0.55$ & $38.65 \pm 1.23$ & $Z=4.112$ & $<0.001$ \\
\hline Birth weight [kg] & $3.95 \pm 0.64$ & $3.49 \pm 0.31$ & $Z=3.118$ & 0.002 \\
\hline Supine length [cm] & $53.68 \pm 4.57$ & $49.95 \pm 1.16$ & $Z=4.195$ & $<0.001$ \\
\hline Ponderal index [kg/cm 3$]$ & $2.28 \pm 0.059$ & $2.26 \pm 0.022$ & $Z=0.123$ & 0.724 \\
\hline Sex [male/female] & $26 / 14$ & $10 / 10$ & & \\
\hline MOD [NVD/CS] & $10 / 30$ & $14 / 6$ & & - \\
\hline Maternal HbA ${ }_{1 c}[\%]$ & $7.64 \pm 0.82$ & - & - & 0.149 \\
\hline Blood glucose $[\mathrm{mg} / \mathrm{dl}]$ & $52.33 \pm 9.69$ & $56.40 \pm 9.33$ & $Z=1.444$ \\
\hline
\end{tabular}

$B M I$ - body mass index, Z - Mann-Whitney U, $t$ - Student's t-test, MOD - mode of delivery, NVD - normal vaginal delivery, CS - caesarean section 
Table II. Comparison between macrosomic and non-macrosomic infants of diabetic mothers as regards clinical and laboratory parameters

\begin{tabular}{|c|c|c|c|c|c|}
\hline \multicolumn{2}{|l|}{ Parameters } & $\begin{array}{c}\text { Group I }(n=20) \\
\text { mean } \pm \text { SD, } n(\%)\end{array}$ & $\begin{array}{l}\text { Group II }(n=20) \\
\text { mean } \pm \text { SD, } n(\%)\end{array}$ & $z / \chi^{2}$ & $\begin{array}{l}\text { Value of } \\
\qquad p\end{array}$ \\
\hline \multicolumn{2}{|c|}{ Duration of maternal DM [years] } & $5.35 \pm 2.65$ & $5.55 \pm 1.98$ & $Z=0.271$ & 0.788 \\
\hline Strict control of DM: & $\begin{array}{l}+\mathrm{ve} \\
-\mathrm{ve}\end{array}$ & $\begin{array}{l}9(45) \\
11(55)\end{array}$ & $20(100)$ & $\chi^{2}=15.17$ & 0.0001 \\
\hline $\begin{array}{l}\text { History of previous } \\
\text { macrosomic baby: }\end{array}$ & $\begin{array}{l}\text { +ve } \\
-v e\end{array}$ & $\begin{array}{l}15(79) \\
4(21)\end{array}$ & $\begin{array}{c}6(37.5) \\
10(62.5)\end{array}$ & $\chi^{2}=8.23$ & 0.016 \\
\hline Sex: & $\begin{array}{l}\text { Male } \\
\text { Female }\end{array}$ & $\begin{array}{l}13(65) \\
7(35)\end{array}$ & $\begin{array}{l}13(65) \\
7(35)\end{array}$ & $\chi^{2}=0.000$ & 1.00 \\
\hline Mode of delivery: & $\begin{array}{l}\text { NVD } \\
\text { CS }\end{array}$ & $\begin{array}{c}0(0) \\
20(100)\end{array}$ & $\begin{array}{l}10(50) \\
10(50)\end{array}$ & $\chi^{2}=13.33$ & $<0.001$ \\
\hline \multicolumn{2}{|c|}{ Gestational age [weeks] } & $37.55 \pm 0.50$ & $37.40 \pm 0.60$ & $Z=0.853$ & 0.399 \\
\hline \multicolumn{2}{|l|}{ Birth weight $[\mathrm{kg}]$} & $4.44 \pm 0.37$ & $3.46 \pm 0.44$ & $Z=7.534$ & $<0.001$ \\
\hline \multicolumn{2}{|l|}{ Supine length $[\mathrm{cm}]$} & $56.20 \pm 2.03$ & $51.15 \pm 5.03$ & $Z=4.161$ & $<0.001$ \\
\hline \multicolumn{2}{|c|}{ Ponderal index [kg/ $\left.\mathrm{cm}^{3}\right]$} & $2.28 \pm 0.07$ & $2.27 \pm 0.03$ & $Z=0.809$ & 0.149 \\
\hline \multicolumn{2}{|c|}{ Triceps skinfold thickness [mm] } & $2.66 \pm 0.38$ & $1.98 \pm 0.33$ & $Z=6.135$ & $<0.001$ \\
\hline \multicolumn{2}{|c|}{ Biceps skinfold thickness [mm] } & $2.00 \pm 0.34$ & $1.48 \pm 0.46$ & $Z=4.098$ & $<0.001$ \\
\hline \multicolumn{2}{|c|}{ Suprailiac skinfold thickness [mm] } & $1.59 \pm 0.32$ & $1.31 \pm 0.50$ & $Z=3.510$ & 0.001 \\
\hline \multicolumn{2}{|c|}{ Subscapular skinfold thickness [mm] } & $1.65 \pm 0.41$ & $1.20 \pm 0.59$ & $Z=2.809$ & 0.008 \\
\hline \multicolumn{2}{|l|}{ Maternal $\mathrm{HbA}_{1 \mathrm{c}}[\%]$} & $8.30 \pm 0.55$ & $6.98 \pm 0.38$ & $Z=8.892$ & 0.001 \\
\hline \multicolumn{2}{|l|}{ Blood glucose [mg/dl] } & $50.45 \pm 9.05$ & $54.20 \pm 10.17$ & $Z=1.232$ & 0.226 \\
\hline \multicolumn{2}{|l|}{ Serum insulin $[\mu \mathrm{U} / \mathrm{l}]$} & $38.55 \pm 46.13$ & $25.17 \pm 15.23$ & $Z=1.231$ & 0.226 \\
\hline \multicolumn{2}{|c|}{ Serum resistin [ng/ml] } & $12.60 \pm 5.73$ & $12.78 \pm 8.42$ & $Z=0.077$ & 0.939 \\
\hline \multicolumn{2}{|l|}{ Adiponectin [ $[\mu \mathrm{g} / \mathrm{ml}]$} & $9.75 \pm 3.22$ & $10.29 \pm 2.99$ & $Z=0.549$ & 0.586 \\
\hline
\end{tabular}

$D M$ - diabetes mellitus, BMI - body mass index, NVD - normal vaginal delivery, CS - caesarean section, Z - Mann-Whitney U, $\chi^{2}$ - chi square test, +ve control of DM - optimal or suboptimal, -ve control of DM - poor

$37.55 \pm 0.60$ weeks. All of them were delivered by caesarean section. Group II included 7 males and 13 females with mean birth weight $3.46 \pm 0.37 \mathrm{~kg}$, mean gestational age $37.40 \pm 0.50$ weeks. Ten neonates (50\%) were born by vaginal delivery and 10 neonates (50\%) were delivered by caesarean section. Group III included 10 males and 10 females, with mean birth weight $3.49 \pm 0.31 \mathrm{~kg}$, mean gestational age $38.65 \pm 1.23$ weeks. Fourteen neonates $(70 \%)$ were born by vaginal delivery and 6 neonates (30\%) were delivered by caesarean section. All skinfold thicknesses were highly significantly increased in infants of diabetic mothers (IDMs) compared to controls ( $p=0.001$ ) (Figure 1 ). Serum insulin was highly significantly increased in IDMs compared to the control group ( $p<0.001)$. On the other hand, serum resistin and adiponectin were significantly decreased in IDMs compared to the control group ( $p=0.005, p=0.017$ respectively) (Figure 2). Mothers of macrosomic IDMs had increased history of previous macrosomic infants, significantly poor control of diabetes, and highly significantly increased $\mathrm{HbA}_{1 c}$ compared to those of non-macrosomic IDMs (Table II). Mean gestational age was comparable in macrosomic and nonmacrosomic IDMs ( $p=0.399)$. Mean birth weight and gestational age were highly significantly increased in macrosomic compared to nonmacrosomic IDMs ( $p<0.001, p<0.001$ respectively), while mean ponderal index was comparable in the two groups ( $p=0.149$ ). Serum glucose, insulin, resistin and adiponectin were comparable in group I and II (Table II). Levels of cord insulin, resistin and adiponectin were comparable in females and males of the control group ( $p=0.09, p=0.439$ and $p=0.50$ respectively). Female IDMs $(n=14)$ had significantly higher cord insulin than males $(n=26)$ (44.36 $\pm 45.36 \mu \mathrm{U} / \mathrm{l}, 25.13 \pm 25.81 \mu \mathrm{U} / \mathrm{l}$ respectively, $p=0.034)$ and highly significantly increased cord resistin compared to males $(17.68 \pm 7.28 \mathrm{ng} / \mathrm{ml}$, $10.0 \pm 5.46 \mathrm{ng} / \mathrm{ml}$ respectively, $p=0.002$ ), while no sex difference was detected in adiponectin level among IDMs (female: $12.6 \pm 3 \mu \mathrm{g} / \mathrm{ml}$, male: 10.5 $\pm 3.9 \mu \mathrm{g} / \mathrm{ml}, p=0.715)$. Mode of delivery had no 


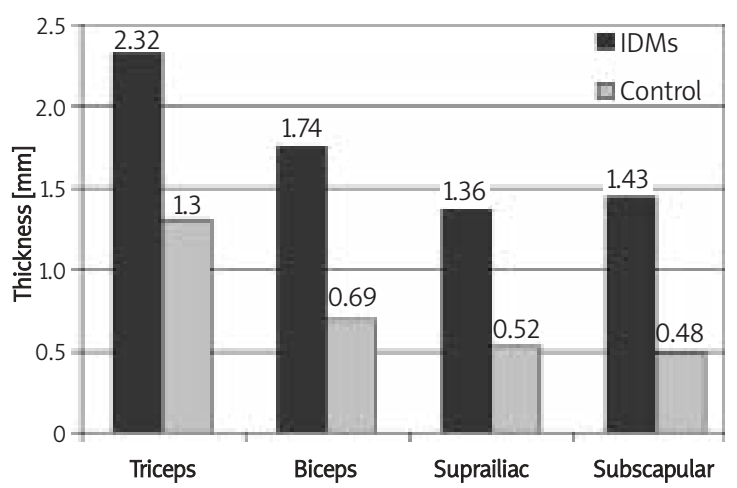

Figure 1. Skinfold thickness among infants of diabetic mothers and control group $(p<0.001)$

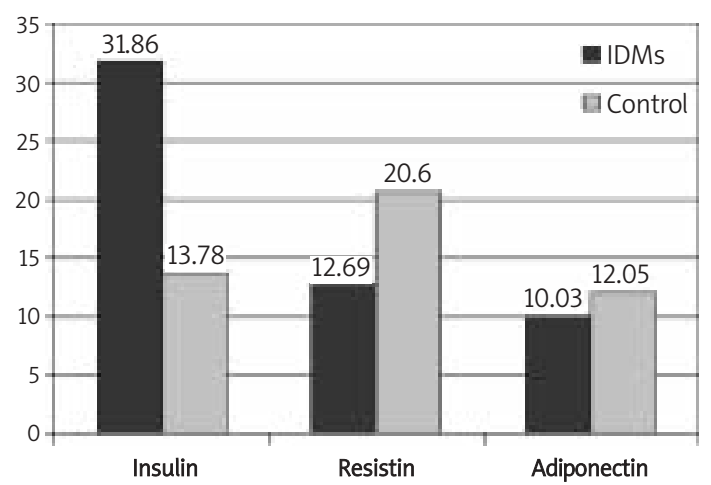

Figure 2. Cord insulin $(\mu \mathrm{U} / \mathrm{l})$, resistin $(\mathrm{ng} / \mathrm{ml})$ and adiponectin $(\mu \mathrm{g} / \mathrm{ml})$ levels among infants of diabetic mothers and controls $(p<0.001, p=0.005, p=0.017$ respectively)

(both macrosomic and non-macrosomic groups) compared to the control group was observed. Fetal hyperinsulinaemia has been detected in offspring of diabetic mothers both in utero by sampling of amniotic fluid [18] and after birth by sampling of cord blood [19]. Fetal insulin production appears to be related to the extent of metabolic abnormality in the fetus and is predictive of both later impaired glucose tolerance and obesity [15].

Resistin was detectable in umbilical serum of all neonates included in this study, at concentrations that ranged from $4 \mathrm{ng} / \mathrm{ml}$ to $37 \mathrm{ng} / \mathrm{ml}$. Similarly, $\mathrm{Ng}$ et al. [7] detected resistin in preterm and full-term healthy newborns and its concentrations were comparable to those in adults. Moreover, resistin has been discovered in human placenta and it has been theorized to play a role in fetal energy metabolism [20].

This study revealed a highly significant decrease in umbilical serum resistin in IDMs (both macrosomic and non-macrosomic groups) compared to the control group, suggesting that the regulation of metabolic pathways by this hormone is probably operational before birth. Insulin has been suggested to be a major inhibitor of resistin production, which was evident from the low resistin mRNA concentrations in insulin resistance [21]. A potential reason for suppressed resistin levels in IDMs is hyperinsulinaemia encountered in them. As resistin could play a pivotal role in inhibiting adipocyte differentiation, the suppressive effect of insulin on resistin might result in eliminating the constraint on the development of new adipocytes. This mechanism might partially explain the excess accumulation of adipose tissue in utero in infants of poorly controlled diabetic mothers [5].

This result confirmed those reached by others who reported that infants of insulin-dependant diabetic mothers were found to have significantly lower serum resistin concentration compared with the normal control group [22]. In addition, previous 
experimental studies reported that exogenous insulin treatment caused a substantial reduction of resistin $\mathrm{mRNA}$ in a time- and dose-dependent fashion in 3T3-L1 adipocytes [23, 24].

In the present study, adiponectin was detectable in umbilical serum of all neonates at concentrations that ranged from $1.5 \mu \mathrm{U} / \mathrm{I}$ to $16 \mu \mathrm{U} / \mathrm{l}$. Cord blood adiponectin level was significantly decreased in IDMs compared to the control group. This finding confirmed previous studies [25, 26]. Furthermore, others found a significant decrease in adiponectin level in full-term LGA newborns in comparison to the AGA group [27]. In contrast, others detected no difference in adiponectin level between full-term IDMs and the control group [28].

Concerning influence of sex on serum insulin, resistin and adiponectin levels, the present study showed that sex has no effect on their concentrations in the control group. Similar results were reached by others $[25,29]$.

On the other hand, female IDMs had a highly significant increase in umbilical serum resistin and insulin levels compared to male IDMs. The same results were obtained by previous studies reporting that female offspring of diabetic mothers had higher insulin concentrations than male neonates [16]. A similar finding as regards resistin was found in adults. Increased resistin levels in females were attributed to higher fat cell mass in the female than the male body [30, 31]. In contrast, $\mathrm{Ng}$ et al. [22] demonstrated no difference in circulating concentrations of resistin and insulin between male and female IDMs.

This study revealed that the mode of delivery had no influence on umbilical serum insulin, resistin and adiponectin in both IDMs and control groups. Similar results were demonstrated by others [25, 29]. On the other hand, $\mathrm{Ng}$ et al. [7] found that serum resistin levels were significantly higher in infants who were born vaginally than those delivered by caesarean section. Elevated resistin level may be related to stress or inflammation induced by vaginal delivery, as resistin is influenced by proinflammatory stimuli or cytokines.

To detect the association of umbilical serum insulin, resistin and adiponectin with the anthropometric indices, a comparison was done between macrosomic and non-macrosomic IDMs. This comparison showed that the concentrations of umbilical serum insulin, resistin and adiponectin were comparable in the two groups. Of the anthropometric parameters studied, only triceps skinfold thickness correlated positively with umbilical serum insulin in all studied groups. In partial accordance with these results, previous studies showed a significant association between serum insulin and birth weight and body length in normal full-term neonates [7]. Other studies reported a non-significant association between serum insulin and anthropometric indices in a group of IDMs [22] and in normal full-term neonates [29].

No correlation was observed between umbilical serum resistin and neonatal anthropometric indices in IDMs in both macrosomic and non-macrosomic and control groups. These results are in agreement with $\mathrm{Ng}$ et al. [22], who found no correlations between serum resistin and neonatal anthropometric parameters (birth weight, length, body mass index, skinfold thickness) in IDMs, but they reported a positive correlation between resistin level and gestational age and anthropometric indices in healthy full-term and preterm neonates of nondiabetic mothers [7]. The pattern of increase of plasma resistin level with advancing gestational age may be related to upregulation of placental resistin expression in late pregnancy. On the other hand, others detected a negative correlation between umbilical serum resistin and neonatal birth weight in a group of healthy full-term neonates. As resistin appears to have an inhibitory effect on adipose conversion, restricting excessive proliferation and accumulation of fat tissue, the low resistin level in serum may reduce the inhibitory effect on adipogenesis, and, accordingly, induce the excess production of adipose tissue in the fetus [29]. Prior studies in mice and humans have shown conflicting results regarding the link between resistin and obesity. Circulating resistin levels were found to be elevated in genetic and diet induced models of obesity [32]. Interestingly, regional variation in the expression of resistin has also been observed in humans. Higher resistin mRNA levels in visceral compared with peripheral fat provides an explanation for the increase in metabolic abnormalities in abdominal obesity [21].

Although no correlation was observed between umbilical serum adiponectin and neonatal anthropometric indices in IDMs (macrosomic and non-macrosomic) and control groups, multiple regression analysis showed that the combined effects of insulin, resistin and adiponectin were highly correlated with birth weight, with adiponectin as the one responsible for this positive correlation. Previous studies confirmed this finding. One study reported that the fetal weight to placental weight ratio index was associated with adiponectin in neonates of type 1 diabetic mothers and in the control group [33]. In addition, cord blood high molecular weight adiponectin level (the active form of adiponectin) was a significant predictor of birth weight and birth length in healthy full-term newborns [34]. Others reported that cord blood adiponectin concentration correlated positively with birth weight, birth length and the sum of the 4 skinfold thickness measurements in term neonates [35]. Moreover, they added that birth length rather 
than body fatness was the only determinant of cord blood adiponectin concentration.

On the other hand, others found no correlation between adiponectin and birth weight when limiting the study to full-term neonates [28]. They hypothesized that adipose tissue possibly exerts negative feedback on adiponectin levels only when it reaches critical mass. Thus, when the total adipose tissue is low, adiponectin positively correlates with birth weight. However, when the quantity of adipose tissue is abnormally high, as in large for gestational age fetuses, the negative feedback intensifies to a degree that depresses the level of adiponectin. Both lack of correlation and lower levels of adiponectin found by Mazakie et al. [22] in large for gestational age fetuses support this hypothesis.

In the present study, no significant correlation was observed between umbilical serum insulin and gestational age in all studied groups. Similar results were obtained by others [7, 29]. In addition, no significant correlation between either umbilical serum resistin or adiponectin and gestational age in macrosomic and non-macrosomic IDMs and control groups was detected in this study. Similarly, previous studies detected a non-significant correlation between umbilical serum resistin and gestational age in a group of healthy full-term neonates [29]. On the other hand, Ng et al. [7], and Pardo et al. [36], reported that serum resistin and adiponectin levels are positively correlated with gestational age and their concentrations are significantly higher in term than in preterm infants, suggesting that these hormones could be gestation related and might play an important role in regulating energy metabolism and adiposity in utero. The increase in plasma concentrations with advancing gestational age might merely reflect a larger adipose tissue mass at the late stages of pregnancy. Moreover, several studies have reported that resistin is generated in the placenta and the human resistin gene is expressed in human placental tissue [20]. It is speculated that the placental production of resistin constitutes the principal cause of the increase in levels of serum resistin with advancing gestational age [37]. Different results were obtained in the current study as all of the neonates included were full-term neonates.

In the current study, a significant positive correlation was observed between umbilical serum resistin and glucose level in both macrosomic and non-macrosomic IDMs. This significant correlation was not found in the control group. Functionally, resistin impairs glucose tolerance, resists insulin action, and increases hepatic glucose production [38]. A similar positive correlation was detected in adults [39]. In discordance with these results, previous studies found no significant correlation between serum resistin and serum glucose in a group of IDMs [22] and in healthy full-term and preterm neonates [7]. They reported that the lack of a significant correlation between resistin and glucose might suggest that resistin was not involved directly in the regulation of metabolism in utero.

In the present study, neither umbilical serum resistin nor adiponectin correlated with serum insulin. Similar findings were reported in IDMs $[22,40]$ and in healthy full-term neonates [7, 29, 41]. Furthermore, Lee et al. [32] reported that neither transcriptional regulation of the resistin gene nor circulating resistin levels correlated with serum insulin. However, others found a positive correlation between serum resistin and insulin. A previous study on rodents showed that resistin levels were significantly elevated and concordant with increasing levels of insulin [39]. A similar finding was reported in humans, where resistin expression was induced by insulin treatment [5, 42]. These conflicting results could be attributed to differences in study groups, different parameters within the same group such as age and fitness, different sampling procedures whether cultured adipocytes or serum, and different measurement techniques whether resistin mRNA or serum resistin concentrations.

In the current study, no significant correlation was found between umbilical serum resistin and maternal $\mathrm{HbA}_{1 \mathrm{c}}$ in both macrosomic and nonmacrosomic IDMs. This result was similar to previous studies reporting a non-significant correlation between umbilical serum resistin and maternal $\mathrm{HbA}_{1 \mathrm{c}}$ in IDMs [22].

In conclusion, infants of diabetic mothers had elevated levels of cord serum insulin and suppressed levels of cord serum resistin and adiponectin, suggesting that the regulation of these metabolic pathways is probably operational before birth. Levels of the three hormones were comparable in both macrosomic and non-macrosomic neonates. Although no correlation was observed between umbilical serum resistin and adiponectin individually with neonatal anthropometric indices, their combined effects together with insulin were highly correlated with birth weight, with adiponectin as the one responsible for this positive correlation.

\section{References}

1. Lu HL, Wang HW, Wen Y, Zhang MX, Lin HH. Roles of adipocyte derived hormone adiponectin and resistin in insulin resistance of type II diabetes. World J Gastroenterol 2006; 12: 1747-51.

2. Felipe F, Bonet ML, Ribot J, Palou A. Modulation of resistin expression by retinoic acid and vitamin A status. Diabetes 2004; 53: 882-9. 
3. Steppan CM, Bailey ST, Bhat S, et al. The hormone resistin links obesity to diabetes. Nature 2001; 409: 307-12.

4. Nogueiras R, Barreiro ML, Caminos JE, et al. Novel expression of resistin in rat testis: functional role and regulation by nutritional status and hormonal factors. J Cell Sci 2004; 117: 3247-57.

5. Kim KH, Lee K, Moon YS, Sul HS. A cysteine-rich adipose tissue specific secretory factor inhibits adipocyte differentiation. J Biol Chem 2001; 276: 11252-6.

6. Degawa-Yamauchi M, Bovenkerk JE, Juliar BE, et al. Serum resistin (FIZZ3) protein is increased in obese humans. J Clin Endocrinol Metab, 2003; 88: 5452-5.

7. Ng PC, Lee CH, Lan CW, Cham IH, Wong E, Fok T. Resistin in preterm and term newborns: Relation to anthropometry, leptin and insulin. Pediatr Res 2005; 58: 725-30.

8. Lewandowski KC, Szosland K, Horn R, Brabant G, Lewiński A. Short-term lifestyle intervention significantly increases fasting adiponectin and induces a decline in serum adiponectin during oral glucose tolerance test, without changes in insulin resistance. Arch Med Sci 2006; 2: 179-84.

9. Hu E, Liang P, Spiegelman BM. AdipoQ is a novel adipose specific gene dysregulated in obesity. J Biol Chem 1996; 271: 10697-703.

10. Hotta K, Funahashi T, Arita Y, et al. Plasma concentrations of a novel, adipose specific protein, adiponectin, in type 2 diabetic patients. Arterioscler Thromb Vasc Biol 2000; 20: 1595-9.

11. Weyer C, Funahashi T, Tunaka S, et al. Hypoadiponectinemia in obesity and type 2 diabetes: close association with insulin resistance and hyperinsulinemia. J Clin Endocrino Metab 2001; 86: 1930-5.

12. Hoggard N, Haggarty P, Thomas L, Lea RG. Leptin expression in placental and fetal tissues: does leptin have a functional role? Biochem Soc Trans 2001; 29: 57-63.

13. Ballard JL, Khoury JC, Wedig K, Wang L, Ellers-Walsman BL, Lipp R. New Ballard score, expanded to include extremely premature infants. J Pediatr 1991; 119: 417-23.

14. Trinder P. Determination of glucose in blood using glucose oxidase with an alternative oxygen acceptor. Ann Clin Biochem 1969; 6: 24-5

15. Lindsay RS, Walker JD, Halsall I, et al; Scottish Multicentre Study of Diabetes in Pregnancy. Insulin and insulin propeptides at birth in offspring of diabetic mothers. J Clin Endocrinol Metab 2003; 88: 1664-71.

16. Krishnaveni GV, Hill JC, Leary SD, et al. Anthropometry, glucose tolerance, and insulin concentrations in Indian children: relationships to maternal glucose and insulin concentrations during pregnancy. Diabetes Care 2005; 28: 2919-25.

17. González-Quintero VH, Istwan NB, Rhea DJ, et al. The impact of glycemic control on neonatal outcome in singleton pregnancies complicated by gestational diabetes. Diabetes Care 2007; 30: 467-70.

18. Weiss PA, Scholz HS, Haas J, Tamussino KF, Seissler J, Borkenstein $\mathrm{MH}$. Long-term follow-up of infants of mothers with type 1 diabetes: evidence for hereditary and nonhereditary transmission of diabetes and precursors. Diabetes Care 2000; 23: 905-11.

19. Lawlor DA, Smith GD, Ebrahim S. Birth weight of offspring and insulin resistance in late adulthood: cross sectional survey, crossectional survey. BMJ 2002; 325: 359.

20. Yura S, Sagawa N, Itoh $\mathrm{H}$, et al. Resistin is expressed in the human placenta. J Clin Endocrinol Metab 2003; 88: 1394-7.

21. Ukkola O. Resistin: a mediator of obesity-associated insulin resistance or an innocent bystander? Eur J Endocrinol 2002; 147: 571-4.
22. Ng PC, Lee CH, Lam CW, Wong E, Chen IH, Fok TF. Plasma Ghrelin and Resistin concentration are suppressed in infants of insulin dependant diabetic mothers. J Clin Endocrinol Metab 2004; 89: 5563-8.

23. Kawashima J, Tsuruzoe K, Motoshima H, et al. Insulin down-regulates resistin mRNA through the synthesis of protein(s) that could accelerate the degradation of resistin mRNA in 3T3-L1 adipocytes. Diabetologia 2003; 46: 231-40.

24. Haugen F, Jørgensen A, Drevon CA, Trayhurn P. Inhibition by insulin of resistin gene expression in 3T3-L1 adipocytes. FEBS Lett 2001; 507: 105-8.

25. Lindsay RS, Walker JD, Havel PJ, Hamilton BA, Calder AA, Johnstone FD; Scottish Multicentre Study of Diabetes Pregnancy. Adiponectin is present in cord blood but is unrelated to birth weight. Diabetes Care 2003; 26: 2244-9.

26. Atego JM, Grissa O, Yessoufou A, et al. Modulation of adipokines and cytokines in gestational diabetes and macrosomia. J Clin Endocrinol Metab 2006; 91: 4137-43.

27. Mazaki-Tovi S, Kanety H, Pariente C, Hemi R, Schiff E, Sivan E. Cord blood adiponectin in LGA newborns. Am J Obstet Gynecol 2005; 193: 1238-42.

28. Kajantie E, Hytinantti T, Hovi P, Andersson S. Cord plasma adiponectin: a 20 fold rise between 24 weeks gestation and term. J Clin Endocrinol Metab 2004; 89: 4031-6.

29. Cho GJ, Yoo SW, Hong SC, et al. Correlations between umbilical and maternal serum resistin levels and neonatal birth weight. Acta Obstet Gynecol 2006; 85: 1051-6.

30. Silha JV, Krsek M, Skrha JV, Sucharda P, Nyomba BL, Murphy LJ. Plasma resistin, adiponectin and leptin levels in lean and obese subjects: correlations with insulin resistance. Eur J Endocrinol 2003; 149: 331-5.

31. Yannakoulia M, Yiannakouris N, Blüher S, Matalas AL, Klimis-Zacas D, Mantzoros CS. Body fat mass and macronutrient intake in relation to circulating soluble leptin receptor, free leptin index, adiponectin, and resistin concentrations in healthy humans. J Clin Endocrinol Metab 2003; 88: 1730-6.

32. Lee JH, Chan JL, Yiannakouris N, et al. Circulating resistin levels are not associated with obesity or insulin resistance in humans and are not regulated by fasting or leptin administration: cross-sectional and interventional studies in normal, insulin-resistant and diabetic subjects. J Clin Endocrinol Metab 2003; 88: 4848-56.

33. Nelson SM, Freeman DJ, Sattar N, Lindsay RS. Role of adiponectin in matching of fetal and placental weight in mothers with type 1 diabetes. Diabetes Care 2008; 31: 1123-5.

34. Inone M, Itabashi K, Nakano Y, Nakano Y, Tobe T. High molecular weight adiponectin and leptin levels in cord blood are associated with anthropometric measurements at birth. Horm Res 2008; 70: 268-72.

35. Inami I, Okada T, Fujita $\mathrm{H}$, et al. Impact of serum adiponectin concentration on birth size and early postnatal growth. Pediatr Res 2007; 61: 604-6.

36. Pardo IM, Geloneze B, Tambascia MA, Barros-Filho AA. Hyperadiponectinemia in newborns: relationship with leptin levels and birth weight. Obes Res 2004; 12: 521-4.

37. Chen D, Dong M, Fang Q, He J, Wang Z, Yang X. Alterations of serum resistin in normal pregnancy and pre-eclampsia. Clin Sci 2005; 108: 81-4.

38. Fasshauer M, Paschke R. Regulation of adipocytokines and insulin resistance. Diabetologia 2003; 46: 1594-603.

39. Rajala MW, Qi Y, Patel HR, et al. Regulation of resistin expression and circulating levels in obesity, diabetes, and fasting. Diabetes 2004; 53: 1671-9. 
40. Boney CM, Verma A, Tucker R, Vohr BR. Metabolic syndrome in childhood: Association with birth weight, maternal obesity and gestational diabetes mellitus. Pediatrics 2005; 115: e290-6.

41. Sivan E, Mazaki-Tovi S, Pariente C, et al. Adiponectin in human cord blood: relation to fetal birth weight and gender. J Clin Endocrinol Metab 2003; 88: 5656-60.

42. Way JM, Görgün CZ, Tong Q, et al. Adipose tissue resistin expression is severely suppressed in obesity and stimulated by peroxisome proliferator-activated receptor gamma agonists. J Biol Chem 2001; 276: 25651-3. 